\title{
The discourse of tourism: an analysis of the online article "Best in Travel 2015: Top 10 cities" in its translation to Brazilian Portuguese
}

\author{
Débora de Carvalho Figueiredo* \\ Universidade Federal de Santa Catarina \\ Florianópolis, SC, BR \\ Camila Alvares Pasquetti ${ }^{* *}$ \\ Universidade Federal de Santa Catarina \\ Florianópolis, SC, BR
}

\begin{abstract}
This article presents a critical reading of the text "Best in Travel 2015: Top 10 cities" and its translation to Brazilian Portuguese, both published online in 2014 by one of the world's largest tourism publishing houses, Lonely Planet. The study aims at revising some of the characteristics of the ongoing tourism discourse through an analysis of the network of people and practices involved in these publications, their textual features and images. The theoretical/analytical framework used includes Critical Discourse Analysis and a corpus-based tool used to interpret different aspects of this tourism discourse. The places advertised as "Top 10" are presented to an exclusive audience that must have digital literacy, economic power and the will to consume fetish-like, or "gourmetized" products.
\end{abstract}

Keywords: Critical Discourse Analysis; Tourism; Translation; Lonely Planet

\section{Introduction}

Until not very long ago, with no internet access, travel agencies and printed guidebooks were common sources of information for travelers to plan their trips. But with the rapid growth and popularization of information technology through portable devices in the last two decades, people who want to know about places, lodgings, transportation, real time traffic and activities in a given city have at hand a multiplicity of social networking services and websites that help plan (or simply imagine) their next trips. One of the most recognized publishing houses in the area of travel books is Lonely Planet, which has been producing travel information and phrase books in print and electronic versions in English for the last forty years, and in Brazil since 2012.

The purpose of this article is to analyse and interpret some features of this ongoing global tourism discourse in its translation to the Brazilian context. For this empirical research, a specific text was chosen as a sample to be studied, "Best in Travel 2015: Top 10 cities" together with its translation, "O melhor para 2015: cidades imperdíveis", taken from Lonely Planet websites in English (2015, January 15) and in Portuguese (2015, January 15). These posts are part of a series of "Best of" ("O melhor para"), published on the Lonely Planet websites every year as eye-catching readings that take readers and followers to other products of the company.

\footnotetext{
Débora de Carvalho Figueiredo is an Adjunct Professor at Universidade Federal de Santa Catarina. She has been working with Applied Linguistics, Foreign Language Teaching and, mainly, Critical Discourse Analysis. Figueiredo's research interests include questions of gender, power and identity in professional, media and judicial discourses. E-mail: deborafigueiredo@terra.com.br

${ }^{* *}$ Camila Alvares Pasquetti is a Portuguese and English teacher, translator, and a current doctoral student at PPGI/UFSC. Her main research foci are translation and tourism studies. E-mail: camilapasquetti@yahoo.com
} 
In theoretical terms, Critical Discourse Analysis will help us see how social structures operate, through the mediation of social practices, on the people involved in social events (in the present case, the "agents" responsible for the publication of the Lonely Planet text and its translation). The theoretical framework used in this study includes a review of the 1999 work of Fairclough and Chouliaraki (1999), Fairclough's 2001 and 2003 publications, and Duran Muñoz's article (2011). The term discourse is used here in a general sense for verbal language (and images), but also as an element of social life dialectically related to other nondiscoursal elements (Fairclough, 2003). Discourses are different ways of representing aspects of the world from different perspectives, since "differently positioned social actors 'see' and represent social life in different ways, different discourses" (Fairclough 2001, p. 123). A closer look at the texts through a corpus-based study will help us understand the way the discourse of tourism operates in translation. In order to facilitate a comparison between source and target texts, we will use the COPA-TRAD parallel corpus computer tool (Fernandes \& Silva, 2014). Some of the multimodal aspects of the selected texts, such as web layout and images, will be studied under the light of Kress' work (2004). In the following sections we will present a brief notion of tourism today, the network of practices, people and institutions behind the Lonely Planet texts, company-consumer interaction in English and Portuguese, a textual analysis (linguistic peculiarities of this discourse) and a description of the visual composition of the texts in their respective websites.

\section{Tourism today and the case of Lonely Planet}

The act of traveling has always existed for reasons related to migration, religion, studies, commuting, trade and business. The Greek word tour, which can function as a synonym for travel, means 'making a circle', and has been used for at least 500 years to suggest "a circular trip for pleasure" (Leiper, 2004, p.10). With the development of aviation, mainly from the 1960s and 1970s onward, the era of mass tourism began (Leiper, 2004, p.15) and traveling has become a widespread symbol of social status. An increasing number in the translation of travel information to Brazilian Portuguese shows the strengthening of the tourism market in Brazil, as other travel guide publishers like DK and Rough Guides (in Brazil PubliFolha) attest.

The consequences of global mass tourism today are varied. Through the news media, for instance, off-road small villages such as El Chaltén in Argentina can get on the "top best" list of tourist destinations for millions of people who browse the Lonely Planet website, or their Facebook or Twitter profiles, in different languages. Whether directly participating in the activity or not, mass tourism has a direct impact on the lives of people and their communities.

In Brazil, social mobility and an increase in income from 2003 to 2008 have reflected in an increase in traveling (Ministério do Turismo, 2014, p. 22). With more people buying non-essential goods such as products related to tourism and leisure, more translators are needed to keep businesses going. These translators have to face the obstacles of the immediate time demands, while being responsible for expressing a corresponding image of the company within specific layout constraints.

Texts are essential parts of most social events (Fairclough, 2003). It is through the practices of reading and writing, for example, that companies like Lonely Planet interact with their writers and custumers in different languages. However, although their website links to eight different languages (English, Indian English, French, German, Spanish, Portuguese and Russian), most of Lonely Planet articles are published only in English.

Lonely Planet "top ten" ranking strategy is not new: the series 'Best in Travel' has been published for a few years with different titles such as "Top 10 unforgettable family experiences for 2015", "Top 10 wonders of the small-screen world", "Top 10 wonderful workouts around the globe", and a series of other "top" or "best" lists. The "top 10s" reveal contemporary trends as they point out up-to-the-minute tourism products. By including a place in their top ten lists, Lonely Planet helps gentrify or imprint a new higher status to these destinations. As it happens with ordinary food that becomes sophisticated 
or "gourmetized", well-known world capitals and even off-the-beaten-track destinations become associated with a "cool" travel company. A gourmet product, in a broad sense, can be seen as is an exclusive fetish-like creation, and its concept thus expanded to tourism and the "gourmetization" of places.

As Fairclough states, "all [social] practices are practices of production-they are arenas within which social life is produced, be it economic, political, cultural or everyday life" (2001, p. 122). In the case of the Lonely Planet website, social life is being produced here through virtual forms of interaction between producers and consumers, under circumstances that reshape traditional ways of reading, writing and translating. The great number of hyperlinks on the computer screen (especially on the company's website in English) attests to the fact that reading today does not mean a continuous flow from a beginning to an end, but rather a dynamic activity that depends on readers' choices and clicks. As Kress puts it

Contemporary texts-whether information books of all kinds, web-pages, the screens of $\mathrm{CD}$ ROMs, and so on-in their increasingly often image-like textual organization, ask the reader to perform different semiotic work, namely to design the order of the text for themselves. (2004, para. 3)

This way, it is possible nowadays to have a wider idea of the network implied in the discourse of tourism by observing some of the myriad of pages that can be originated one from another. The genres, or diverse ways of acting through language (Fairclough 2001, p. 123), present in the Lonely Planet website are those of reading and writing. If in the past writers were professional travel writers and editors, today readers can become writers when they have their tweets retweeted or when they comment on the company's Facebook posts.

\section{People behind texts and technology}

One difference between the source text (version in English) and the target text (version in Portuguese) can be found in their references to people behind them, or in the answer to the question "who is responsible for this post?". On their 2015 "Best in Travel - Top 10" web page, Lonely Planet's authors highlight that "experts have decided on the best cities to visit this year", while in the translation to Portuguese one can read on the first paragraph of "O melhor para 2015: cidades imperdíveis" (para. 1) that

Após semanas de intensos debates entre os autores-viajantes da Lonely Planet, além de editores e membros da nossa comunidade online, garimpamos entre centenas de sugestões as melhores cidades para visitar em 2015.

In addition to this blurring of agency, if in the English version we have the names of each of the top 10 writers, in the Brazilian website we do not have access either to names of writers or translators. The same happens with other published articles. Therefore, we can ask who is responsible for the company's trademark and how English and Portuguese readers interact.

An analysis of the network of practices would demand a review of the profile of the institution which produced these publications. Lonely Planet is one of the largest travel information and guidebook publishers in the world today. The company was created in the early 1970s by a married couple who, besides traveling to non-mainstream places, started writing and selling stapled booklets with tourist information about low budget traveling (Brennan, 2013, para. 3). In 2007 the company was sold to the BBC, who kept its successful production and also launched a TV series with its name which, however, did not last long. With a decline of print guide books after 2008 (Clampet, 2013, para. 4), Lonely Planet managers began to invest heavily on online products. In 2013 the company was purchased by NC2 Media, as stated on "The Lonely Planet Story" section of their website.

According this same text (n.d., para.8), today the company has offices in Australia, UK, USA, India and China, over 400 employees and 200 authors. Lonely Planet's mission is not stated on their website, but on other websites which sell their publications, like in Amazon.com, where it is said that their "mission" is "to enable curious travellers to experience the world and 
truly get to the heart of the places they find themselves in" ("Lonely Planet The World," 2014, para. 4). As stated in their Brazilian website, Lonely Planet writers are journalists and professional writers that "find and advertise trips and costumes only known by natives" (“Sobre a Lonely Planet", n.d., para. 4).

The number of writers and editors involved in this particular publication makes it difficult to map how individual identities compose the whole product. Things get even fuzzier in relation to the translated text, since we do not know who did the job and why there are omissions from one version to another. As can be seen in their printed materials, the company's translators are various but only some of their works on the web show the credits (not the text studied here). Although Lonely Planet states that the practice of tipping travel writers does not happen, this does not mean that the international branch does not have agreements with other companies promoted on their texts. The "Best in Travel 2015" articles, for instance, are all sponsored by MSN, the Microsoft web portal.

\section{Company-consumer interaction in English and in Portuguese}

The list of people who have contributed to the company so far is huge and their popularity under the Lonely Planet stamp is confirmed among travelers of different profiles. At the moment we are writing this article, the number of likes on Lonely Planet Facebook page in English is of a million and three hundred thousand people; their Twitter account shows more than two million followers. In their Brazilian network services (there are no versions of the website in European Portuguese), Facebook gets more attention than Twitter, with around eleven thousand "likes" for the former against less than two thousand "followers" for the latter. The company's headline on Twitter stimulates reader participation by retweeting what they consider to be the best followers' tweets. Much of the content is repeated in these social networking sites, ${ }^{1}$ where posts like the ones below can be read. The first was retrieved from Facebook on January, 17, 2015 and the second from Twitter, on January, 29, 2015:
Got a great picture of your Lonely Planet in the wild? Send your action shots to community@ lonelyplanet.com and we'll post it here.

Guidelines for submissions: http://bit.ly/ V4QEnZ

Don't miss our New in Travel \#LPChat with @umarket TOMORROW! How to take part: http://bit.ly/1t2hm0I \#lp

These calls to interaction, however, are not found in the Portuguese text. Lonely Planet bio on their Twitter explains, step-by-step, how to participate in their page: “Tweeting (\& RT'ing) the best in travel. 1/Follow us $2 /$ Tag your tweets with \#lp 3/We read your posts $4 / \mathrm{We}$ re-tweet the best of them". These sentences may sound very odd to people who are not used to social media language. At the Lonely Planet bio in the Brazilian Twitter, one can read a simpler slogan "Lonely Planet. O mundo te espera" and no call for custumer participation. In addition, Twitter seems to be less popular among the Portuguese speaking audience when compared to Facebook. For some reason, the Brazilian branch of the company does not invest much on communicating with their present and prospective customers.

Lonely Planet communication in English combines institutional and individual voices by simulating social relations, a strategy which tends "to mystify social hierarchy and social distance" (Fairclough $2003,76)$. The reader who tweets, likes and posts on their social media in English is, in the end, led to believe they are somehow part of the enterprise, as if custumers and company staff had the same authority, or at least the same right to authorship. In relation to Brazilian Portuguese, however, the distance between individuals and the institution looks greater, since the Brazilian version does not ask readers to tweet or post their comments. It is more difficult for the readers of Portuguese to establish a horizontal communication with Lonely Planet as is suggested in the English site. Besides, on Lonely Planet Facebook page in English products are advertised in a personal tone, directed to specific people through their names, tackling their doubts and suggesting places to go by redirecting followers to their online guidebook shop, like in this 
response to a custumer's post about things to do in France from December, 2014

Lonely Planet: Hi Jocelyn -- we agree this is a great part of France, and note some of our top picks for visiting this region here: http://www. lonelyplanet.com/.../burgundy-and.../sights...

Less visited, Lonely Planet Facebook page in Portuguese in 2014 has fewer articles published, few readers' comments and no responses from the company. The article "O melhor para 2015: cidades imperdíveis" was posted on December 8, 2014 on Lonely Planet Brasil's Facebook page; it has received twelve likes and no comments so far. This is an example of the lack of interaction between the company and its Brazilian audience at that moment. If compared to other posts, the number of comments in this specific one is not significantly different. The contents of other Facebook and Twitter posts in Portuguese include shorter translations of texts produced in English or direct ads to their guidebooks with links to their store, usually without readers' comments.

In Brazil, Lonely Planet website is connected to Editora Globo, a publishing house owned by the largest media conglomerate in Latin America. Also known as Globo Livros, the company has firmed a contract with LP, and since 2012 their travel guides and some of the online content have been translated to Brazilian Portuguese. On the Lonely Planet website in Portuguese there is a banner at the top which is familiar to most Brazilians: that of Globo (G1), which leads to their media content.

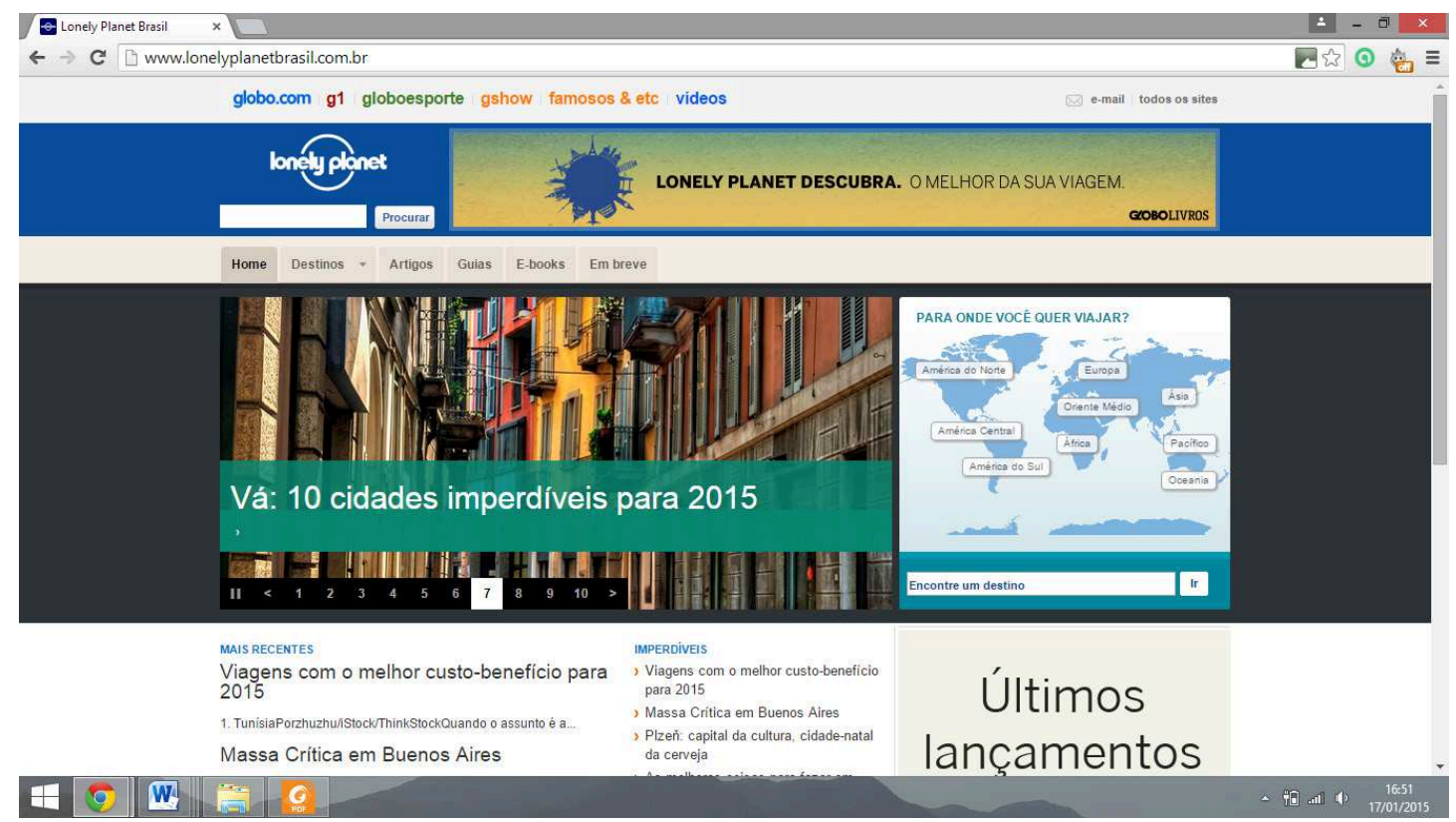

Retrieved from: http://www.lonelyplanetbrasil.com.br/ (2015, January 17)

With a different layout, the Lonely Planet website in English shows a more diverse content. On the top center users find the "Best in travel 2015" launchings and on the third square on the bottom from right to left, amidst 24 square images, we find the link "Best in Travel 2015". 


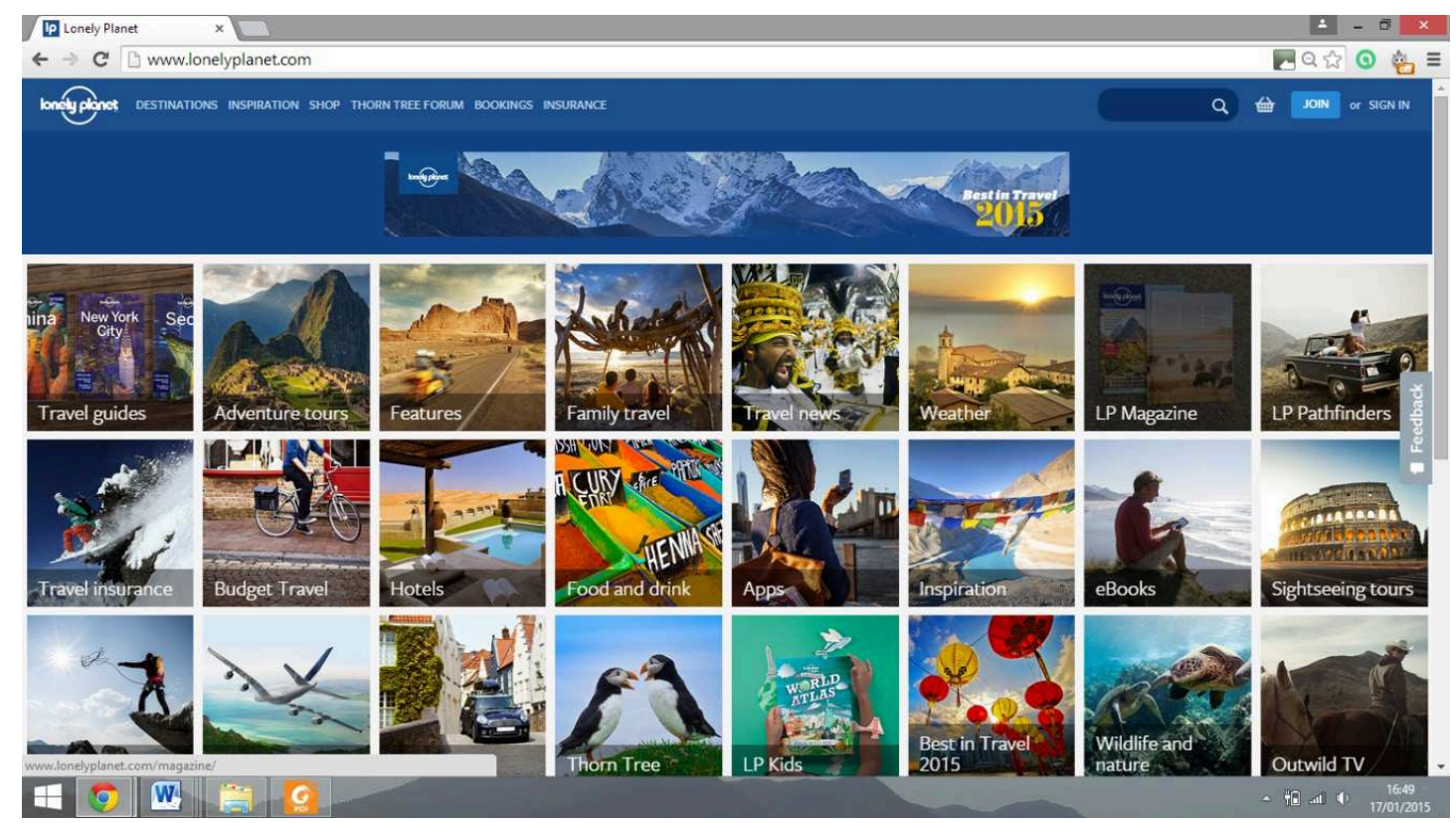

Retrieved from: http://www.lonelyplanet.com/ (2015, January 17)

The page in Portuguese offers options of texts whose titles (or links) are repeated in the "mais recentes" ("most recent") and "imperdíveis" ("unmissable") sessions, indicating that there are few articles at the readers' disposal. At Lonely Planet Descubra, and by browsing the world map on the right, readers find links to other free tips and to the company's travel guides. With far less options of free articles than the version in English (as it happens with other translations of the webpage, such as into Spanish and French), the session "Best of" in Portuguese is limited. Visually, www.lonelyplanet. com is a more colorful, better displayed and thus more attractive website than its Brazilian counterpart.

\section{Text analysis}

As we could see from the examples of Lonely Planet online services, contemporary tourism discourse represents, on the one hand, the process of commodification of language (homogenization) and, on the other, a mixture of voices and people, opening a certain space for creativity and differentiation. The company's text style is based on informality, jokes and cultural references, which function as bridges between the company and its readers, leading to different hybridizations and interpretations. Nonetheless, in order to read the website in English, a non-fluent speaker would need to have either a slang dictionary at hand or a deep knowledge of idioms. It is worth noticing that the use of idioms also creates challenges for translators.

In her study on the translation of the discourse of tourism, Durán Muñoz (2011) affirms that the language of tourism is a "specialized discourse". To her, this discourse borrows terminology from other disciplines (geography, economics, history and sport, etc.) and uses:

- $\quad$ positive adjectives

- $\quad$ superlatives

- lexical choices to comply with the tourist's expectations about holidaying (keywords such as adventure, imagination, pleasure, escape)

- psychological themes (romanticism, rebirth, fantasy, socialization)

- foreign and invented words to induce a sense of the exotic

- cultural references (which do not have equivalents in the target language) 
- comparison, testimony and humor

Superlative and positive adjectives in particular stand out in the analyzed articles. The word "top" can function either as a noun or an adjective in a text, and its translations uncover very different meanings, according to the distinct contexts of use. With source and target texts aligned in COPA-TRAD it is possible to see that translations of "top" into Brazilian Portuguese include the expressions "uma das melhores", "está lá no topo"2, "o grande chapéu" (from "top hat", instead of “cartola”), and "excelentes" (from “top-notch").

\begin{tabular}{|c|c|}
\hline Texto Fonte & Texto Alvo \\
\hline \multicolumn{2}{|l|}{3 resultado(s). } \\
\hline $\begin{array}{l}\text { Washington is one of the top museum and monument } \\
\text { cities in the world and the Smithsonian Institution, a } \\
\text { network of } 19 \text { museums, a zoo and several research } \\
\text { centres, is a top draw. And this year marks the 150th } \\
\text { anniversary of Abraham Lincoln's assassination. }\end{array}$ & $\begin{array}{l}\text { Washington é uma das melhores cidades do mundo } \\
\text { para visitar museus e monumentos, e a Smithsonian } \\
\text { Institution, uma rede de } 19 \text { museus, um zoológico } \\
\text { e vários centros de pesquisa, está lá no topo dessas } \\
\text { atrações. O ano de } 2015 \text { também marca os } 150 \text { anos do } \\
\text { assassinato do presidente Abraham Lincoln, }\end{array}$ \\
\hline $\begin{array}{l}\text { Lincoln's famous top hat, the pistol that fired the deadly } \\
\text { shot and other artifacts from that fateful day will be on } \\
\text { display. }\end{array}$ & $\begin{array}{l}\text { O grande chapéu de Lincoln, a pistola responsável por } \\
\text { sua morte e outros artefatos do dia fatídico estarão } \\
\text { expostos pela cidade. }\end{array}$ \\
\hline $\begin{array}{l}\text { Add to this a vibrant gay bar scene, incredible ethnic } \\
\text { eats thanks to thriving immigrant communities (like } \\
\text { top-notch Ethiopian) and a venerable performing arts } \\
\text { tradition at venues like the Kennedy Center, and the } \\
\text { nation's capital is looking more epic than ever. }\end{array}$ & $\begin{array}{l}\text { Some a tudo isso animados bares gays, restaurantes } \\
\text { étnicos incríveis (como os excelentes etíopes) e uma } \\
\text { venerável tradição de artes performáticas em teatros } \\
\text { como o Kennedy Center, e a capital norte-americana } \\
\text { mostra que está mais épica do que nunca. }\end{array}$ \\
\hline
\end{tabular}

Retrieved from: http://copa-trad.ufsc.br/\#online-concordancer (2015, January 18)

Because it allows us to compare words in their contexts, this corpus analysis tool can easily show other possible translations of words besides the ones found in dictionaries. It is also easier to visualize the informality of Lonely Planet textual style ("lá no topo", "restaurantes étnicos incriveis"), which may be a feature of the language of tourism as a whole, with heavy use of adjectives. Other features of tourism discourse as proposed by Durán Muñoz are expectations, psychological themes and the sense of exotic, all directed to the tourist-reader. These features are, once again, a fertile ground for the "gourmetization" of traveling.

A bit of the language of interaction can be examined in the translations of the only pronoun used in the texts, "you", and its surrounding vocabulary. Concerning syntactic features, Muñoz points out some characteristics of the specialized discourse of tourism, such as the use of:

- passive forms

- imperatives

- simple present tense (in order to make the time of the holiday seem still and everlasting)

- present participles

The main speech functions of tourism discourse are informing (informing about and describing a country, for instance), and persuading (also known as the vocative function ${ }^{3}$ ). Pronoun collocation, syntactic features and speech functions can be examined in the 
text excerpts presented in the next chart. These are four out of eleven occurrences of the word "you" and their respective translations to Portuguese selected at random as a smaller sample.

\begin{tabular}{|c|c|}
\hline Texto Fonte & Texto Alvo \\
\hline $\begin{array}{l}\text { Take a stunningly beautiful Zermatt, raze everything } \\
\text { over two storeys (or three stars!), fill it with a motley } \\
\text { collection of artisans, entrepreneurs and students, add a } \\
\text { gaucho or two, then turn a cyclone loose, and you'll be } \\
\text { getting close to the vibe of Argentina's newest city. }\end{array}$ & $\begin{array}{l}\text { Pegue a deslumbrante Zermatt, tire tudo que tenha mais } \\
\text { de dois andares (ou três estrelas!), preencha de novo } \\
\text { com artesãos, empreendedores e estudantes, um ou dois } \\
\text { gauchos e solte um ciclone por ali: pronto, você está se } \\
\text { aproximando da atmosfera da mais jovem das cidades } \\
\text { argentinas - }\end{array}$ \\
\hline $\begin{array}{l}\text { Make no mistake, it's Los Glaciares that people come to } \\
\text { see, and there are plenty of trails, views and peaks for } \\
\text { enthusiasts of all capabilities, from half-day lakeside } \\
\text { meanders to fully tooled weeklong sorties out on the } \\
\text { ice cap. And if walking or getting vertical doesn't do it } \\
\text { for you, consider horseback, mountain bikes, fishing or } \\
\text { sucking on a hand-crafted ale among other diversions. } \\
\text { Officialdom is refreshingly laid-back. }\end{array}$ & $\begin{array}{l}\text { É claro que são Los Glaciares que todo mundo quer } \\
\text { ver, mas, se escaladas e trilhas não são exatamente a } \\
\text { sua praia, outras opções da região são andar a cavalo, } \\
\text { mountain bike, pesca ou se agarrar a uma boa cerveja } \\
\text { artesanal. }\end{array}$ \\
\hline $\begin{array}{l}\text { No sweat if you're not superhuman or even a climber: } \\
\text { nail-biting theatre recreating Whymper's historic ascent } \\
\text { (and disastrous descent) will take to the open-air stage } \\
\text { in Zermatt town. The backdrop? Au naturel of course - } \\
\text { and as effortlessly sensational as you would expect from } \\
\text { this seductive natural beauty of a town: the mountain } \\
\text { itself! }\end{array}$ & $\begin{array}{l}\text { Mas não se desanime se não for um super-homem ou } \\
\text { mesmo um montanhista: haverá também uma peça } \\
\text { recontando a história subida de Whymper (e trágica } \\
\text { descida) no palco ao ar livre da cidadezinha de Zermatt. } \\
\text { Ao fundo? A natureza em toda a sua majestade, claro. }\end{array}$ \\
\hline $\begin{array}{l}\text { If you like it then you should put a ring on it. Emperor } \\
\text { Franz Josef didn't need Beyoncé to tell him that. In } 1865 \\
\text { the last significant Hapsburg monarch got cracking on } \\
\text { his architectural tour de force: the Ringstrasse }\end{array}$ & $\begin{array}{l}\text { Se você ama de verdade, dê logo um anel- como diria } \\
\text { Beyoncé. -O Imperador Francisco José, no entanto, não } \\
\text { precisou desse conselho da cantora. Em 1865, o último } \\
\text { monarca importante da dinastia Habsburgo coroou as } \\
\text { suas ambições arquitetônicas com a Ringstrasse (rua- } \\
\text { anel, literalmente). }\end{array}$ \\
\hline
\end{tabular}

Retrieved from: http://copa-trad.ufsc.br/\#online-concordancer (2015, January 18)

As we can see, in both source and translated texts we have the presence of the present participle in "you'll be getting close / você está se aproximando" which, without the future form "will", produces in Portuguese a stronger suggestion of a virtual trip. We find a variation in pronoun use in the Portuguese translation of "you" into "sua", because here the translator had to deal with the idiom "doesn't do it for you" and attempted to include the tourist-reader through an expression which cannot be translated literally into Portuguese. The solution given by the translator can rarely be found in dictionaries but seems to fit well an informal style: "não são exatamente a sua praia". The chunk "if you're not superhuman" was translated to Portuguese with the help of the subjunctive "se você não for", demonstrating that other verb tenses in Portuguese can substitute the simple present in English.

The declarative mood is recurrent in the English version of the website, associated with modal verbs that express suggestion or probability, as in "If you like it then you should" or "Go now. You'll have a ball". In contrast, the Portuguese version opts for the use of 
the imperative, expressing commands: "Se você ama de verdade, dê logo..."; "Vá para Viena. E encante$s e$ ". These selected fragments also show an attempt to include different readers by giving them alternatives that they can identify with.

As for cultural references, they remain one of the biggest challenges to translators in the two texts. Difficulties in this sense lie in the translation of proper names, typical dishes, place names, etc. Problems are solved through different strategies, such as we see in the use of additions to the target text (in italics): "Ringstrasse (rua-anel, literalmente)"; "a nova estação de trem, a Hauptbahnhof". The sentence that contains the French expression au naturel was omitted in the target text, demonstrating one possible way of dealing with foreign references.

It is worth noticing that the target text is just a small part of the source text; to be more precise, the target text is a selection of the first paragraph of each city on the list in English. In addition to this major cut, another $20 \%$ of the source article was elided: the version in Portuguese joins parts of the selected paragraphs by cutting (editing) and sewing all textual content into one single text. That is, what we get in the Brazilian Portuguese translation is a tiny bit of the text published in English, which suggests either that the cost of translation is high, the storage of a long text online is problematic or that the Brazilian audience does not respond to large amounts of reading.

\section{A tour around images}

However meaningful, words seem to play a secondary role in new multimedia texts like the ones studied here. Persuasion, attraction and seduction, "often considered to be the trigger elements to tourists when deciding where to go or what to visit before and during the visit" (Durán Muñoz, 2011, p. 36), are frequently achieved through pictures. Images, then, should not be undervalued when writing and translating tourism genres. Moreover, computer screen images should be given special focus since, as Kress (2004, para. 19) suggests, "the screen is the site of the image and the logic of the image is shaping the order and the arrangements of the screen". From this position, writing is now subordinated to the logic of the image.

In the Lonely Planet pages, differences in images in the source and target texts are noticeable in every screen. In https://www.lonelyplanet.com/best-intravel/cities, readers have to browse through one page per city, seeing a big picture of the place on the back, a small paragraph, and two options to click on: a "tell me more" link and an arrow to skip to the next place on the list. The "tell me more" link opens to a text with headings such as "Life-changing experience", "Classic restaurant experience", "Best shopping" and "Classic place to stay", all absent in the Portuguese version. The order of arrangements on the target screen layout is also less complex in the Brazilian version: there are no colors other than on the background and less font type and size variation.

Another difference is that, if on the one hand the website in English states the names of writers, on the other hand in Portuguese they state the names of photographers and the source of the pictures, a stock photo agency that sells images online, Getty Images. The screen size pictures behind the title, heading and first paragraphs show cities with buildings or landscapes with the sky behind them but no people on close up shots. In fact, only in the Washington D.C. picture is there a human figure seen from afar, whose image is blurred; this is the single human presence we see in all "Top 10 cities" pictures. The same characteristic absence of human figures can be seen in the images available on the Brazilian Lonely Planet website. Though some of the pictures shown in the translated texts are different, all of them are also devoid of human figures.

Below are the screen images of number three city, El Chaltén, in Argentina. In the Brazilian Portuguese page, the presence of a line of local animals creates an interplay with the heading "Vá antes que as trilhas fiquem movimentadas." After this ad, they might as well get crowded. 


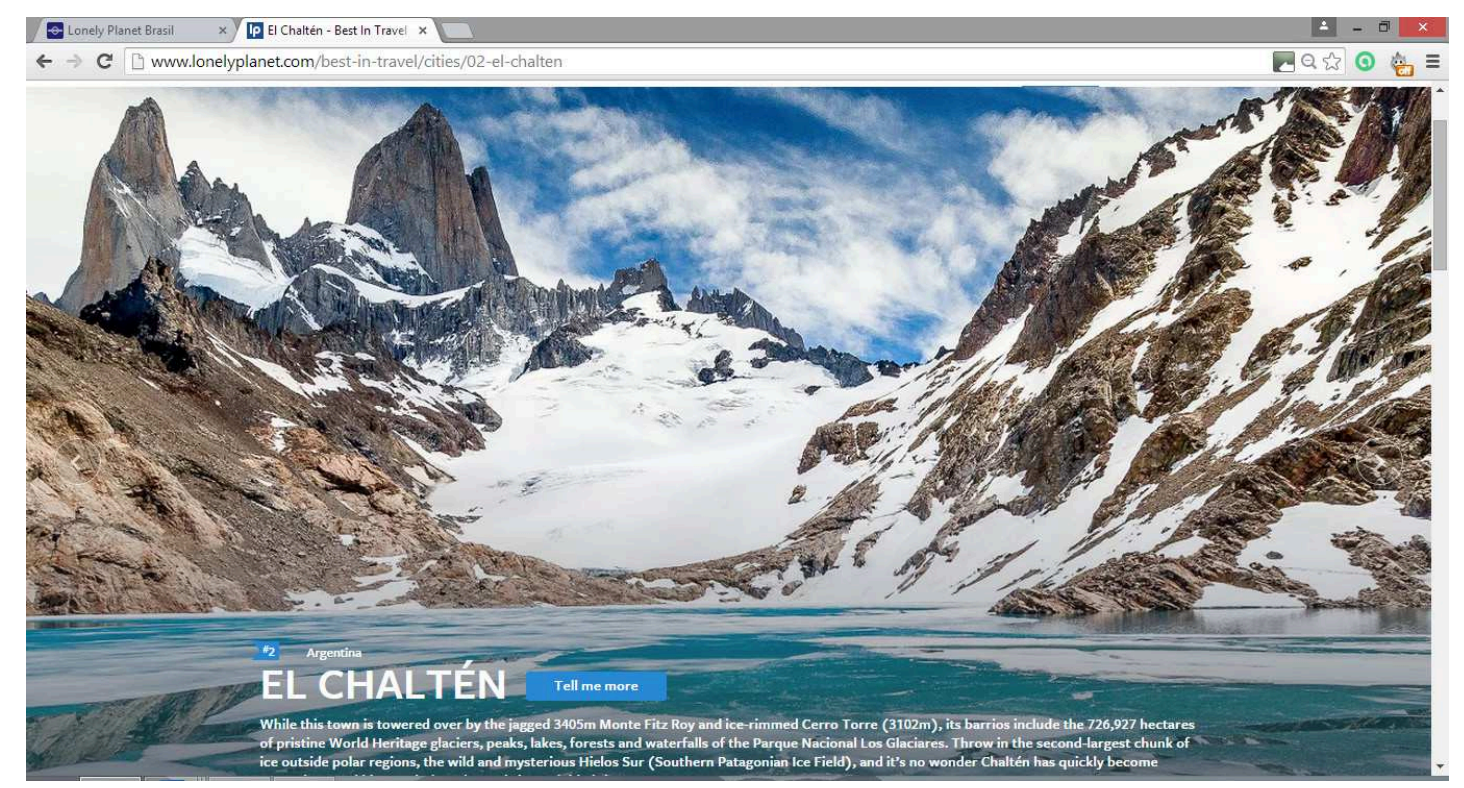

Retrieved from: http://www.lonelyplanet.com/best-in-travel/cities/02-el-chalten (2015, January 30)

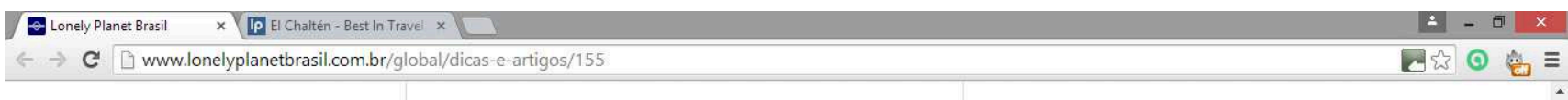

\section{El Chaltén, Argentina}

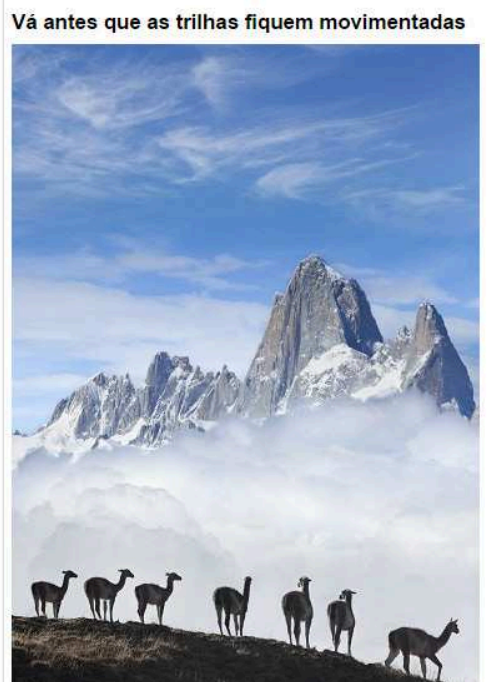

Retrieved from: http://www.lonelyplanetbrasil.com.br/global/dicas-e-artigos/155 (2015, January 30)

Natural elements and architecture are part of the imagery of tourism. In both Lonely Planet websites pictures usually do not include any human presence. Most of these images are also ahistorical in the sense that they can represent anytime in the past or present. In terms of distance, images on the webpage in English occupy a greater space on the screen than on its Portuguese counterpart as can be seen above. They are thus closer to their readers, an effect that suggests a call to participation. It is more pleasant, after all, to do some virtual traveling through larger images than from afar, with small ones. Seduction is an element that seems to be more current in the original website than in its translation to Portuguese because of its colorful design, size and number of pictures. 


\section{Final Remarks}

From the examples analysed in this article, we could see that, in its translation to Brazilian Portuguese, the tourism discourse of Lonely Planet is marked by a whole set of changes in text, images and web layout. From the texts selected for translation and made available in Brazilian Portuguese, we can see that the text producers cut, changed images and altered their disposition on the screen. What is offered to Portuguese speakers is, therefore, a processed slice of a global product. Nonetheless, the absence of people is a common characteristic of the pictures in both articles. Social hierarchy is more visible in the version in Portuguese than in the English one, since there is less company-custumer interaction in the Portuguese version, like company calls for tweets and posts.

Textual analysis through a parallel corpus study has shown that the source text presents an informal style through the use of idioms and abundant cultural references, which are typical of tourism discourse as a whole and which represent challenges to translators. Different solutions were given by the Brazilian translators in each context, according to the meaning of the sentence and purpose of the text. The idea that the texts are speaking directly to their readers is reinforced by the number of occurrences of "you" in English and their correspondents in Portuguese. An informal tone prevails in both versions, which is that of a conversation with readers-tourists-custumers, bringing the company closer to their clients. Differences in interaction in the target culture when compared to the source culture, however, indicate a larger distance between the Brazilian branch of the company and its customers.

The study of the images displayed in the translated and source texts reveals absences, such as images of people in close-ups. The absence of people in Lonely Planet ads may also point to a company's strategy of avoiding discussions on ethnical and identity issues through representations of human bodies, a characteristic of traditional tourism ads. Cities and landscapes shown in an indefinite moment of history reinforce the discourse of the empty exotic land ready to be fulfilled by the tourist at any time-preferably right now, before it gets crowded, as one of the analysed texts claim. Not by chance these pictures mirror the name of the company: a lonely planet, empty of people, ready for "your" individualized tourism experience to take place.

This discourse seems to be directed to people from higher economic classes, the same ones who can afford accessing, interacting and buying these and other "gourmetized" products as symbols of successful consumer identities. Participation in the social practices of accessing and sharing travel experiences requires digital literacy and reflects a present-time form of control, since internet sites are heavily monitored by enterprises, friends and followers.

As for the role of translators, similar to travel writers, these are highly flexible workers from our present fragmented work relations: they can both produce from a distance and also make their homes their offices. A drastic reduction on the cost of production is then operating underneath the tourism products of today.

The international discourse of tourism and its translation is thus a fertile ground for a critical understanding of our current practices as producers and consumers of leisure. If we want to go further on the study of global tourism discourse, however, a larger multilingual corpus would be necessary. Registering and analyzing website movements can also reveal more about the dynamics of this global multilingual discourse.

\section{Notes}

1. There are five other social networking sites linked on the website in English and three in Portuguese.

2. In English, "top draw", an expression whose definition can only be found in informal dictionaries, meaning "feeling absolutely perfect" (http://www. urbandictionary.com/define.php?term=Top+Draw)

3. Nouns, pronouns, or adjectives used in direct address to indicate the person or thing addressed (The Collins Online Dictionary).

\section{References}

Brennan, E. (2013, June 7). A Lonely Planet Founder Looks Back. Retrieved from http://www.nytimes. com/2013/06/09/travel/a-lonely-planet-founderlooks-back.html?_r=1 
Caldas-Coulthard, C. (2008). Body branded: Multimodal identities in tourism advertising. Journal of Language and Politics, 451-470.

Chouliaraki, L. Fairclough, N. (1999). Discourse in late modernity. Edinburgh: Edinburgh UP, 1-74.

Clampet, J. (2013, March 4). UPDATED: Lonely Planet and the rapid decline of the printed guidebook. Retrieved from http://skift.com/2013/03/04/lonely-planet-andthe-rapid-decline-of-the-printed-guidebook/

Durán Muñoz, I. (2011). Tourist translations as a mediation tool: misunderstandings and difficulties. Retrieved from https://periodicos.ufsc.br/index.php/ traducao/article/view/2175-7968.2011v1n27p29

Fairclough, N. (2003). Analysing discourse: Textual analysis for social research. London: Routledge.

(2006). Language and globalization. London: Routledge.

(2001). In: Wodak, R; Meyer, M. (Eds). Critical discourse analysis as a method in social scientific research. In: Methods of critical discourse analysis. London: Sage, 121-138.

Fernandes, L. P. (2004). A Portal into the Unknown: Designing, Building, and Processing a Parallel Corpus. CTIS Occasional Papers, V. 4, 16-36.

Fernandes, L. P. \& Silva, C. E. (2014). COPA-TRAD (Corpus Paralelo de Tradução). Retrieved from http:// copa-trad.ufsc.br

Kress, G. (2004). Reading Images: Multimodality, Representation and New Media. Retrieved from http:// www.knowledgepresentation.org/BuildingTheFuture/ Kress2/Kress2.html

Filo, K \& Wang, Y. (n.d.) Will Consumers Pay for News Content Online: The Implications for Tourism. Retrieved from http://www98.griffith.edu.au/ dspace/bitstream/handle/10072/41509/73939_1. pdf? sequence $=1$

Leiper, N. (2004). Tourism Management. (3rd Ed.). Frenchs Forest, NSW: Pearson Education Australia.

Lonely Planet. (n.d.) Best in Travel 2015 - Top 10 Cities. Retrieved from http://www.lonelyplanet.com/best-intravel/cities

Lonely Planet Brasil. (2014, November 17). O melhor para 2015: 10 Cidades imperdiveis. Retrieved from http://www.lonelyplanetbrasil.com.br/global/dicas-eartigos/155

Lonely Planet. (January 17 and 29, 2015). [Tweet]. Retrieved from https://twitter.com/lonelyplanet_br

Lonely Planet Brasil. (January 18, 2015). [Tweet]. Retrieved from https://twitter.com/lonelyplanet
Lonely Planet. (January 18, 2015). [Facebook status update]. Retrieved from https://www.facebook.com/ lonelyplanet?fref $=$ ts

Lonely Planet Brasil. (January 18, 2015). [Facebook status update]. Retrieved from https://www.facebook.com/ lonelyplanetbrasil? fref $=$ ts

Lonely Planet The World: A Traveller's Guide to the Planet Paperback (2014, November 1). Retrieved from http://www.amazon.com/Lonely-Planet-The-WorldTravellers/dp/1743600658

Ministério do Turismo. (2014). Documento referencial turismo no Brasil 2011-2014. Retrieved from http://www.turismo.gov.br/turismo/o_ministerio/ publicacoes/cadernos_publicacoes/21Documento_ Referencial.html

Ministério do Turismo. (2015). Dados e Fatos: Estudos, pesquisas e dados sobre o setor de turismo. Retrieved from http://www.dadosefatos.turismo.gov.br/ dadosefatos/home.html

The Lonely Planet Story. (n.d.). Retrieved from http:// www.lonelyplanet.com/about/

Shankman, S. (2013). How Lonely Planet is winning the battle on social media. Retrieved from http://skift. com/2013/03/04/skiftsocial-analysis-how-old-schooltravel-guidebooks-stack-up-on-social-media/

Sobre a Lonely Planet. (n.d.). Retrieved from http://www. lonelyplanetbrasil.com.br/sobre

Recebido em: 9/9/2015 Aceito em: 29/09/2015 